\title{
Containership Flag Selection: The Opening of Direct Shipping between Taiwan and China
}

\author{
Shih-Hao Yang, Cheng-Chi Chung, and Hsuan-Shih Lee \\ Department of Shipping and Transportation Management, National Taiwan Ocean University, Keelung 20224, Taiwan \\ Correspondence should be addressed to Cheng-Chi Chung; jackie@mail.ntou.edu.tw
}

Received 20 September 2013; Accepted 13 February 2014; Published 24 March 2014

Academic Editor: Ching-Ter Chang

Copyright (C) 2014 Shih-Hao Yang et al. This is an open access article distributed under the Creative Commons Attribution License, which permits unrestricted use, distribution, and reproduction in any medium, provided the original work is properly cited.

The signature of the cross-strait sea transport (CST) Agreement in 2008 has not only established the cross-strait direct shipping link, but also lifted the ban on the involvement of Taiwanese flagged ships to call at China's ports. This paper focuses on the flag selection for Taiwanese container shipping companies under the provisions of the CST Agreement, and embraces the empirical investigation based on the Analytic Hierarchy Process (AHP) and Grey Relation Analysis (GRA) with the Technique for Order Preference by Similarity to Ideal Solution (TOPSIS). The results show Hong Kong is the optimal choice rather than China and Taiwan. Although cross-strait shipping is highly controlled by both sides of the strait, economic factors are still taken seriously in commercial activities. Further, to assist shipping companies to get direct shipping approvals from China and revising a package of financial measures under current shipping policies are recommended for the Taiwanese government.

\section{Introduction}

Political differences between Taiwan and China lead to the suspension of direct links via mail, transport, and trade since 1949. Since an "Open Door" policy and economic reform began in China in 1979, the cross-strait relationship has gradually thawed. To satisfy the transport demand, two major modes of transport for cross-strait sea transport were widely adopted by shipping companies in the past decades. One is that ships can carry cross-strait trade cargoes as international routes by sailing via a third place nearby befEmployment of ore they call in at the ports of Taiwan or China, such as Hong Kong or Ishigaki island. By adopting this mode, additional cost, time, and risk will occur and therefore reduce the competitiveness of the shipping companies. Another way is sailing through "Offshore Shipping Center," which may directly sail between Kaohsiung and Fuzhou or Xiamen carrying foreign trade cargoes of China through transshipment at Kaohsiung in Taiwan to a third place. However, cargoes delivered by "Offshore Shipping Center" neither get customs clearance nor enter Taiwan. The restrictions on direct shipping across the Taiwan Strait not only cause the operating inefficiency of shipping companies, but also lead to the decline of Taiwanese national merchant fleet. FOC (flag of convenience) ships were common in the use of trading by shipping companies, in order to avoid the national flag controversy. Path across the Taiwan Strait without direct shipping is shown in Figure 1.

In recent years, intense trade activities between Taiwan and China highlighted the direct shipping issue. According to the statistical data from the Ministry of Finance [1] in Taiwan, the trade values between Taiwan and China increased from US $\$ 33,909$ million in 2003 to US $\$ 121,622$ million in 2012, with an annual growth rate of $15.25 \%$. In addition, trade values between Taiwan and China accounted for $21.3 \%$ of the foreign trade values of Taiwan in 2012. The ten-year trend of trade values between Taiwan and China is shown in Figure 2 .

In response to the rapid growth of trade activities between the two sides of the strait, Taiwan and China finally reached an Agreement on direct shipping issues. In the Second Chiang-Chen Meeting held on November 4, 2008, the cross-strait sea transport (CST) Agreement was signed, and direct shipping began on December 15, 2008. The significant benefits of direct shipping are lowering trade costs and risks by reducing transit time. Considering that transport demand is an extension of trade, direct shipping has positive impacts on economic growth for Taiwan. According to the CST Agreement, both sides agreed only that Taiwanese or Chinese ships registered in Taiwan, Hong Kong, or China 


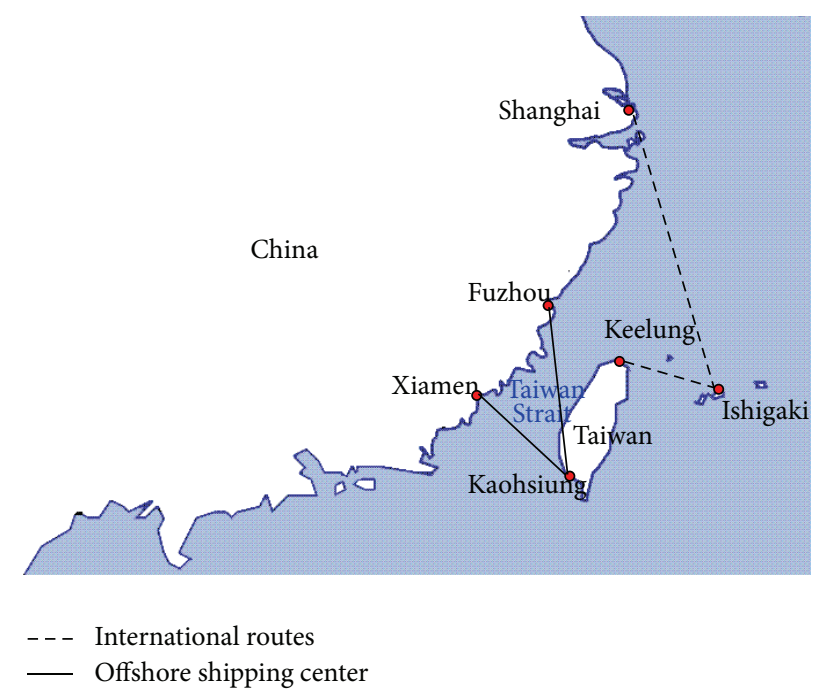

FIgURE 1: Path across the Taiwan Strait without direct shipping.

have the qualification to run the cross-strait shipping route, and foreign ships are excluded by principle. (According to the CST Agreement, the qualifications of ships which are allowed to operate direct shipping across the Taiwan Strait are as follows [2]. (i) Ships owned and registered on either side of the Taiwan Strait may, with due approval, engage in direct cross-strait carriage of cargos and passengers, (Art. 1). (ii) Ships owned by companies on either side (Taiwan and China) of the Taiwan Strait and registered in Hong Kong may similarly engage in direct cross-strait transport of cargos and passengers, (Art. 1 in Annex). (iii) FOC ships owned by shipping companies on either side of the Taiwan Strait and which are currently already engaging in the Offshore Shipping Center (or called "Test Point for Direct Shipping") transport, cross-strait third-territory container line transport, and sand and gravel transport, having obtained special permits, may, in compliance with the provisions concerning ship identification set out in the Agreement, undertake direct CST (Art. 2 in Annex.) In other words, Taiwanese shipping companies running the direct shipping business have to register ships' flag in Taiwan, Hong Kong, or China through a joint venture.

The role of seaborne trade has been the backbone of economic development [3]. The national merchant fleet is a driver for the development of the shipping industry [4]. However, the percentage of ships flagging out in Taiwan is more serious than the global average. One of the most important reasons is the prohibition against direct shipping across the Taiwan Strait [5-8]. The provisions of the CST Agreement may have a greater impact on Taiwanese container shipping companies because they might have to input a fleet rather than a ship to operate a shipping route in order to offer regular schedules and weekly services. The service network planning is a very important activity as once the service is launched it will be difficult or costly to alter it the short run [9]. Moreover, in confront with the great change of crossstrait shipping environment, Taiwanese shipping companies

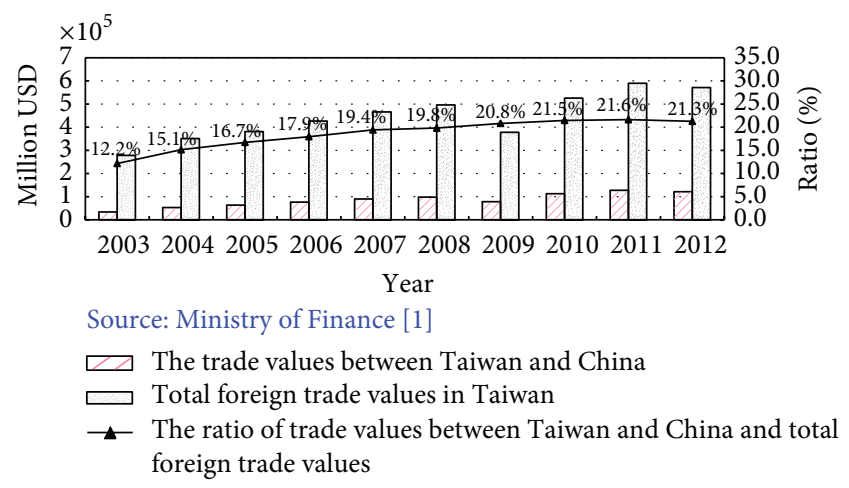

Figure 2: The trade values between Taiwan and China.

also express interest in the choice of having their ships flagged in one of these three locations in order to undertake direct cross-strait shipping carriage. Reviewing previous studies, Lin et al. [10] have already analyzed the optimal selection of different types of registers for Taiwanese container shipping companies. However, they did not discuss this core issue under the new regulation of the CST Agreement. This study strives to explore the optimal flag selection for Taiwanese container shipping companies under the provisions of the CST Agreement. The Analytic Hierarchy Process (AHP) method is applied to evaluate the weight of each criterion, subcriterion, and the performance of the alternatives. The methods of Grey Relation Analysis (GRA) and Techniques for Order Preference by Similarity to Ideal Solution (TOPSIS) are conducted to evaluate the containership registrations among Taiwan, Hong Kong, and China. The results from the analysis can serve as a good reference not only for the Taiwanese container shipping companies in selecting the ship's flag to undertake direct cross-strait shipping carriage, but also for Taiwanese government in revising relevant shipping policies.

The rest of this paper is organized as follows. Section 2 is a literature review. Section 3 introduces methodologies. Sections 4 and 5 present the empirical results and the discussion of the analysis, respectively. The concluding remarks are addressed in the last section.

\section{Literature Review}

Selecting the flag of a ship is a crucial issue in a successful shipping business because the economics of running a merchant ship are closely related to ship registration [11]. Bergantino and O'Sullivan [12] also pointed out that the purpose of changing a ship's registry for shipowners is to pursue the liberalization of business activity. This section reviews previous studies on the reasons for flagging out and shipping registry selection.

2.1. Reasons for Flagging Out. Flag selection is a complex process influenced by multifactors [13-15]. Recent literature has shown shipowners flag out mostly because of economic considerations $[9,16-19]$. Cost differences among various forms of register result in the switching of a ship's flag [20]. 
Haralambides and Yang [17] mentioned that flagging out is an "internationalization" strategy to change a ship's registry from an "expensive" to a "cheap" flag. Relative factors influencing flag selection include crew costs $[6,8,10-13,16-18,20-27]$, tax liabilities $[6,8,10,13,17,18,20,22,23,27,28]$, finance and capital costs $[6,8,10,11,13,17,18,20,22,23]$, lighter maintenance and safety compliance costs $[13,17,23,26-28]$, and other costs.

Operational flexibility is another important reason for shipowners to flag out $[10,11,17,20]$. It can be treated as an attempt to self-deregulate the sector on the part of the shipping industry [27]. Relative factors influencing flag selection include safety standards and maintenance requirements $[6,8$, $10,17,18,20,22]$, freedom to use foreign crews $[10,13,18,20]$, the recruitment of qualified crews $[11,21,26,28]$, minimal bureaucracy $[6,8,10,13,17,20,22,23,26,27]$, trading limits $[6,8,10,13,17,20]$, and easy access to an open registry $[20,27]$.

There are other factors influencing shipowners for flag selection, such as public relations reasons [13, 17, 27], ship's characteristics $[13,17,23,27]$, comparative advantages of country $[17,22,23,27]$, historical reasons [13, 27], political reasons $[16,18,23,26,28]$, military reasons $[16,28]$, trade union considerations $[6,8,17]$, and corporate culture and structure $[20,27]$.

2.2. Ship Registry Selection. Ship registry selection has been discussed continually for years. Cullianane and Robertshaw [20] concentrated on the economic reasons why shipowners flag out to register other than with their home register. They pointed out the criteria for selecting Isle of Man registration were total cost, freedom to trade, market valuation, insurance, national allegiance, and quality of register. They also mentioned a shipowner's choice of register is obviously not influenced by cost alone. Bergantino and Marlow [13] examined the factors affecting flag selection for the UK shipping industry, finding that the type of ships and crew costs are the most important reasons for using or not using the national flag, respectively. Veenstra and Bergantino [27] examined changes in ownership of the Dutch fleet for two years after the new shipping policy was introduced in 1996. They broke the determinants of flagging out into two large categories: endogenous and exogenous factors and pointed out the exogenous factors have more impact on the location of the shipping companies. Alderton and Winchester [16] compared the regimes of FOCs using the flag state conformance index (FLASCI) and measured each state's capacity to maintain and enforce a regulatory regime for flying a flag. They found the cluster of new FOCs countries that lacked formal regulation and the capacity and willingness of the state to take responsibility for these actions.

Based on the Fuzzy Set Theory (FST) and the AHP method, Haralambides and Yang [17] applied the Comprehensive Fuzzy Evaluation (CFE) Model to assess how the factors influence flag choices among national registry, second registry, and open registry regimes. Twelve influential factors were divided into three categories: economic, societal, and political. The results showed crew cost is the most important factor, and the second registry is the optimal choice for the ship registry. Llácer [18] reviewed flagging out results from political and economic reasons. He pointed out that the New Greek legislation aimed at guaranteeing employment and Greek seafarer wages forced shipowners to flag out to avoid double tax payment. In addition, the advantages yielding lower crew cost, freedom to use foreign labor, together with low taxes, and safety matters have been essential pillars for considerations of open register. Further, banks' powerful positions also influence shipowners in choosing registers. Hoffmann et al. [29] posited two functions to estimate the probability of the choice of foreign flag by shipowners. Via Binominal Probit Analysis, they found ship age, carrying capacity, ship size, and ship type will make shipowners choose a foreign flag. Hwang and Chung [8] developed a hierarchical evaluation framework consisting of four aspects, which were policy, cost, operation, and market, to analyze related factors' degree of influence on ship registrations of bulk shipping companies. The result showed reducing operational cost is the most important objective.

Chung et al. [6] adopted the AHP method and developed a hierarchical analysis framework with four criteria and thirteen subcriteria to analyze the key factors for containership registrations in Taiwan. The results showed economic factors and trading area restrictions are the most important criterion and subcriterion, respectively. Celik et al. [22] applied the Fuzzy Extended AHP (FEAHP) method to structure a practical decision to support the mechanism for ensuring multicriteria analysis of shipping registry selection among Turkey, Panama, and Malta. The results showed Malta was the best shipping registry among the alternatives, and economic considerations were the dominant factor in shipping registry selection. Mitroussi and Marlow [30] pointed out strategic management decisions and the human resource management process most seriously affected the choice of flag between open registers and national flags. First, open registers and national registers correspond to cost leadership and a differentiation strategy. On the other side, human resource planning, such as recruitment, selection process, training, development, and performance appraisal programs are affected. Lin et al. [10] adopted the AHP and GRA model to evaluate the relative attractiveness of different types of registers for Taiwanese container shipping companies, finding the FOC countries were the most preferred locations. Celik and Kandakoglu [23] adopt the quantified SWOT approach under fuzzy AHP as a strategy development and evaluation tool. Furthermore, the ranking of the proposed strategies against the flagging out problem is presented via the flagging out strategy development and evaluation matrix (FODEM). The results showed that reducing the tax-related expenses is the most urgent strategy on preventing the flagging out problem in the Turkish shipping industry.

Literatures related to the selection of shipping registry are listed by years in Figure 3. The issue of selecting the ship flag determines shipping companies' competitiveness, and a variety of analytical models have been adopted by past literature. It is not only helpful for authors to understand the development of this core issue, but also valuable to collect relevant factors which influence flag selection and build an analyzing framework. 


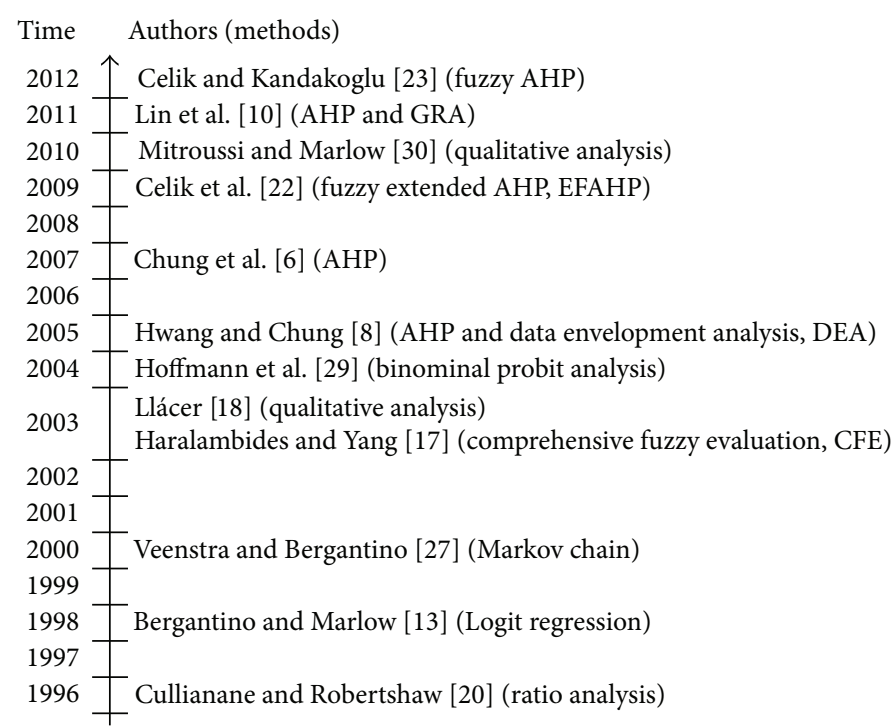

FIGURE 3: Literature related to the selection of ship registry.

\section{Methodologies}

Flag selection is generally based on the experience of highlevel managers $[13,17,30]$. The AHP method is applied in this study to evaluate the weight of each criterion, subcriterion, and the performance of alternatives. In addition, the method of GRA is applied to fit the characteristic of the small sample size resulting from minor participants in the decision making, and the performance scores and outranking are calculated by the TOPSIS method. Their operational steps are described as follows.

3.1. Questionnaire Process. The questionnaire for the survey was developed in the following phases.

Phase 1: Forming an AHP Framework. We collect the influential factors for flag selection through literature reviews and discuss with high-level managers in container shipping companies. And, the earlier structures formed by Lin et al. [10] were adopted as the basis for adjustment for interview because it is the latest structure and it has the similar sample group with this study. After interviewing with five high level managers who belong to container shipping companies, three factors (registry qualifications acquired, direct shipping licenses, and prohibition of the employment of Chinese seafarers) are suggested to be included within the framework. In addition, one criteria (adapting to market environments) and four subcriteria (cross-strait trading limits, insufficient incentives, complying with ITF requirements, and trading area restrictions) should be deleted because they do not match the current situation or have no difference on flag selection among three alternatives. After renaming some subcriteria as needed and all experts agreed, a hierarchy is formed for pretest.

Phase 2: Pretest. One survey form was designed according to the forming AHP framework. Then the questionnaire was pretested by sending it to five high-level managers in container shipping companies to check whether the contexts and expressions on the form were precise and easy to understand. The survey form was modified and revised according to suggestions from the pretest.

Phase 3: Posttest. The revised questionnaire was tested again with the same number of container shipping companies to ensure that all the contexts and expressions were accurate and that all of the important factors were included. The decision-making hierarchy is finally established in this phase. In the light of Saaty's [31] opinion, human beings can simultaneously compare up to seven items. This study breaks twelve items into three criteria, including the government policies, economic factors, and operational flexibility. The operational flexibility refers to the factors commonly affecting the daily operation of a ship. The evaluation framework is shown in Figure 4.

Phase 4: The Questionnaire Survey. Three parts of the questionnaire survey form were designed under the principles of the AHP method. The first part introduces the background information; the second part includes a pairwise comparison of every hierarchical element, and the last part includes basic information on the interviewed experts and their companies. The questionnaire was finalized with twelve question items as shown in Table 1.

3.2. Determining the Weight of Criteria by Using the AHP Method. The Analytic Hierarchy Process (AHP) method was first introduced by Saaty in 1971. It is a multicriteria decisionmaking (MCDM) method using hierarchical structures to represent a decision problem, which then develops priorities for the alternatives based on the decision maker judgments throughout the system [31]. The AHP method provides a framework for planning, priority setting, and resource allocation [32]. By using AHP, the complex MCDM problems can 


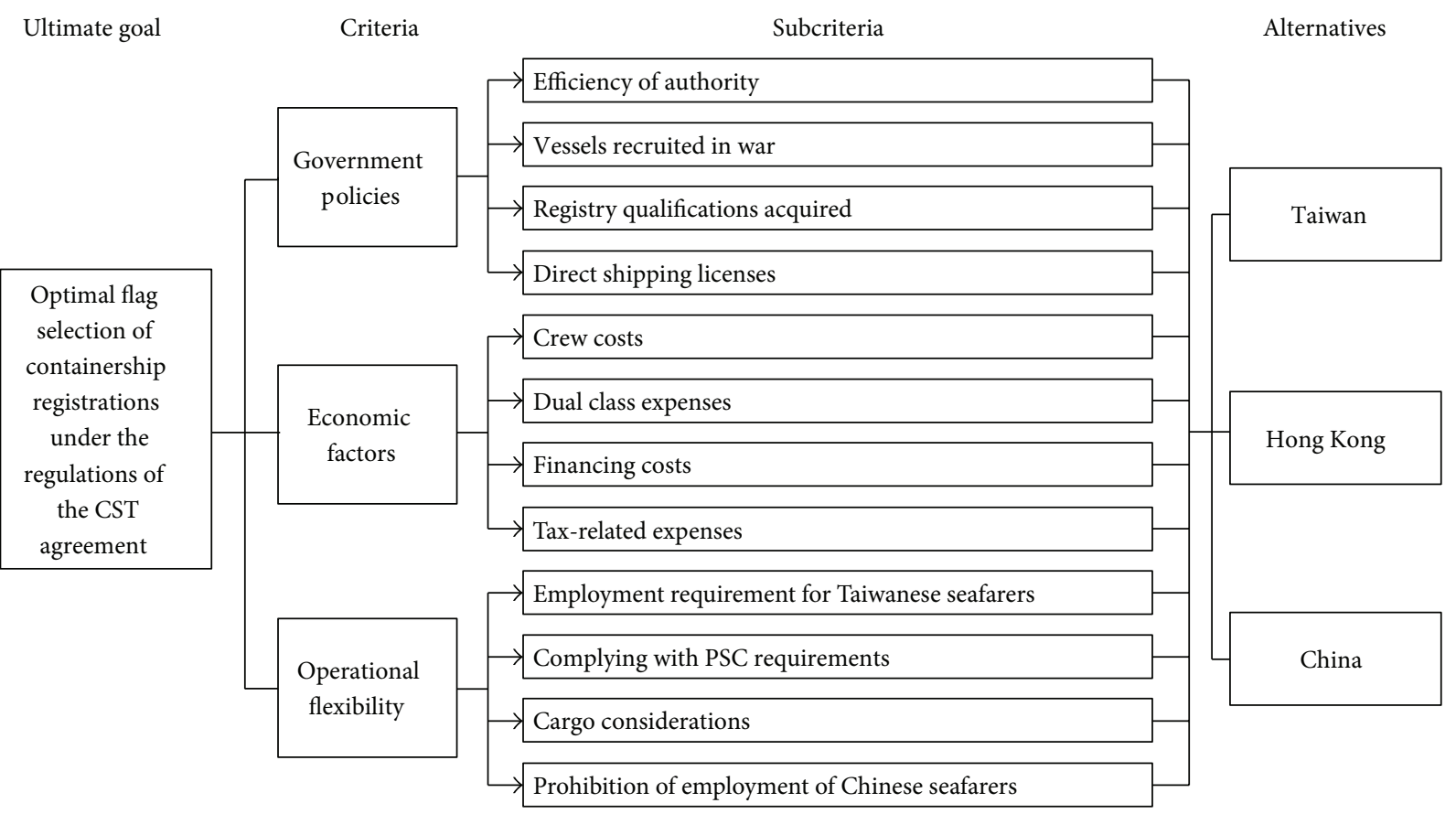

FIGURE 4: The hierarchy for flag selection.

TABLE 1: Flag selection items used for surveys.

\begin{tabular}{|c|c|}
\hline Items & Descriptions \\
\hline Efficiency of authority & Authority's efficiency in processing ships register. \\
\hline Vessels recruited in war & The obligation of ships recruitment in war. \\
\hline $\begin{array}{l}\text { Registry qualifications } \\
\text { acquired }\end{array}$ & $\begin{array}{l}\text { The complexity to fit in with registry qualifications acquired by the Agreement; for example, Taiwanese } \\
\text { container shipping companies who want to register their ships in China have to apply business strategies } \\
\text { such as joint venture with Chinese companies to meet China's close registry system. }\end{array}$ \\
\hline Direct shipping licenses & The different difficulty level of acquiring approvals between Taiwan and China. \\
\hline Crew costs & The different level of crew costs resulting from different manning policy requirements in register location. \\
\hline Dual class expenses & $\begin{array}{l}\text { Ships registered in Taiwan have to prepare both certifications issued by China Corporation Register of } \\
\text { Shipping (CR) and one of the members of International Association of Classification Societies (IACS). }\end{array}$ \\
\hline Financing costs & Ship register in different location accompanies with different level of financing costs. \\
\hline Tax-related expenses & Different level of tax-related expenses among Taiwan, Hong Kong, and China. \\
\hline $\begin{array}{l}\text { Employment requirement } \\
\text { for Taiwanese seafarers }\end{array}$ & $\begin{array}{l}\text { Ships registered in Taiwan have to meet the requirement of the Regulations Governing the Management } \\
\text { and Employment of Foreign National Seafarers. }\end{array}$ \\
\hline $\begin{array}{l}\text { Complying with PSC } \\
\text { requirements }\end{array}$ & Ship's register location is an important checking item for port state control (PSC) inspection. \\
\hline Cargo considerations & $\begin{array}{l}\text { Shipping companies that registered their ships in a location which have sufficient cargoes might have more } \\
\text { opportunity to expand business scale. }\end{array}$ \\
\hline $\begin{array}{l}\text { Prohibitions of the } \\
\text { employment of Chinese } \\
\text { seafarers }\end{array}$ & $\begin{array}{l}\text { Seafarers from China have become the majority of foreign seafarers employed by Taiwanese shipowners, } \\
\text { but state-owned ships in Taiwan cannot recruit seafarers from China. }\end{array}$ \\
\hline
\end{tabular}

be decomposed into a hierarchy by integrating the decisionmakers' experience, intuition, and knowledge. The main characteristic of the AHP method is the pairwise comparison judgments [33], and the advantages of easy implementation, simple structure, speed, and robustness [34] make AHP method widely applied.
The operation steps are as follows.

Step 1 (establishment of pairwise comparison matrix A). Let $C_{1}, C_{2}, \ldots, C_{n}$ denote the set of elements, while $a_{i j}$ represents a quantified judgment on a pair of elements $C_{i}$ and $C_{j}$. The relative importance of two elements is rated using a scale with 
the values $1,3,5,7$, and 9, where 1 refers to "equally important," 3 denotes "slightly more important," 5 equals "strongly more important," 7 represents "demonstrably more important," and 9 denotes "absolutely more important." This yields a $n \times n$ matrix $A$. This $n \times n$ matrix $A$ is as follows:

$$
A=\begin{gathered}
C_{1} \\
C_{1} \\
C_{2} \\
\vdots \\
C_{n}
\end{gathered}\left[\begin{array}{cccc}
1 & a_{12} & \cdots & a_{1 n} \\
a_{21} & 1 & \cdots & a_{2 n} \\
\vdots & \vdots & \ddots & \vdots \\
a_{n 1} & a_{n 2} & \cdots & 1
\end{array}\right]
$$

where $a_{i j}=1$ and $a_{j i}=1 / a_{i j}, i, j=1,2, \ldots, n ; a_{i j}$ represents the pairwise comparison rating between elements $i$ and $j$ of a level with respect to the upper level.

Step 2 (determining the priorities of elements of different levels). The priorities of the elements can be estimated by finding the principal eigenvector $w$ of matrix $A$. If $A$ is a consistency matrix, eigenvector $w$ can be calculated by

$$
A W=\lambda_{\max } W
$$

where $\lambda_{\max }$ is the largest eigenvalue. After vector $w$ is normalized, the priority weights of criteria and subcriteria are

$$
W=\left(w_{1}, w_{2}, \ldots, w_{n}\right)^{T} .
$$

Step 3 (performing the consistency test). The consistency of the judgmental matrix proposed by Saaty [31] can be determined by a measure called the consistency ratio (CR). If $\mathrm{CR} \leqq 0.1$, then the estimation is accepted. The CR is defined as

$$
\mathrm{CR}=\frac{\mathrm{CI}}{R I}
$$

where $\mathrm{CI}$ is called the consistency index (CI) and for a matrix of order $n$ is defined as

$$
\mathrm{CI}=\frac{\left(\lambda_{\max }-n\right)}{(n-1)}
$$

and $R I$ represents the average consistency index over numerous random entries of the same order reciprocal matrices.

\subsection{Determining the Performance of Register Location by} Using GRA and TOPSIS. Grey Relational Analysis (GRA) was developed in 1982 and was introduced in the Grey System by Ju-Long [35] and Deng [36]. It is a method of measuring the degree of approximation among sequences according to the Grey relational grade. In traditional statistical analysis techniques, the validity is based on assumptions such as the distribution of population and variances of samples.

Ju-Long [35] argued those assumptions do not conform to many real decision situations, and the required sample size may not be financially or pragmatically justified. One of the advantages of the GRA is it requires a smaller number of samples with simple calculations involved. Moreover, there are some advantages, such as a typical distribution of samples is not being needed, the quantified outcomes from the Grey relational grade do not result in contradictory conclusions from the qualitative analysis, and the Grey relational grade model is a transfer functional model that is effective in dealing with discrete data [36]. In addition, the TOPSIS method is applied in conjunction with grey relation analysis to calculate performance scores and rankings; it is an effective method to determine the ranking order of decision alternatives [37]. The basic principle is that the chosen alternative should have the shortest distance from the ideal solution and the farthest distance from the negative-ideal solution [38].

In this paper, the operational steps of the GRA are as follows.

Step 1 (normalized the original sequence). (1) If the target value of original sequence is infinite, then it has a characteristic of "the larger the better." The original sequence can be normalized as follows:

$$
x_{a}(s)=\frac{x_{a}^{O}(s)-\min x_{a}^{O}(s)}{\max x_{a}^{O}(s)-\min x_{a}^{O}(s)} .
$$

$x_{a}^{O}(s)$ is the original sequence; $x_{a}(s)$ is the sequence after the data process; $\forall a=1,2, \ldots, r ; \forall s=1,2, \ldots, p$.

(2) When "the smaller the better" is a characteristic of the original sequence, then the original sequence should be normalized as follows:

$$
x_{a}(s)=\frac{\max x_{a}^{O}(s)-x_{a}^{O}(s)}{\max x_{a}^{O}(s)-\min x_{a}^{O}(s)} .
$$

(3) If there is a definite target value to be achieved, then the original sequence will be normalized in the following form:

$$
\begin{aligned}
& x_{a}(s) \\
& =1-\frac{\left|x_{a}^{O}(s)-O B\right|}{\max \left\{\max x_{a}^{O}(s)-O B, O B-\min x_{a}^{O}(s)\right\}},
\end{aligned}
$$

Step 2. Identify the reference sequences of the aspired $\left(x^{*}\right)$ and worst $\left(x^{-}\right)$values of alternatives by performance matrix:

$$
\begin{aligned}
& x^{*}(s)=\max _{a} x_{a}(s), \\
& x^{-}(s)=\min _{a} x_{a}(s),
\end{aligned}
$$

where $x_{a}$ is alternative $a$.

Step 3. Compute the Grey relational coefficients as the following.

(1) Coefficients of Grey relation for aspired values:

$$
\begin{aligned}
& \gamma\left(x^{*}(s), x_{a}(s)\right) \\
& =\frac{\min _{a} \min _{s}\left|x^{*}(s)-x_{a}(s)\right|+\zeta \max _{a} \max _{s}\left|x^{*}(s)-x_{a}(s)\right|}{\left|x^{*}(s)-x_{a}(s)\right|+\zeta \max _{a} \max _{s}\left|x^{*}(s)-x_{a}(s)\right|} \\
& \quad 0<\gamma\left(x^{*}(s), x_{a}(s)\right) \leq 1, \zeta \in[0,1] .
\end{aligned}
$$


(2) Coefficients of Grey relation for worst values:

$$
\begin{aligned}
& \gamma\left(x^{-}(s), x_{a}(s)\right) \\
& =\frac{\min _{a} \min _{s}\left|x^{-}(s)-x_{a}(s)\right|+\zeta \max _{a} \max _{s}\left|x^{-}(s)-x_{a}(s)\right|}{\left|x^{-}(s)-x_{a}(s)\right|+\zeta \max _{a} \max _{s}\left|x^{-}(s)-x_{a}(s)\right|} \\
& \quad 0<\gamma\left(x^{-}(s), x_{a}(s)\right) \leq 1, \zeta \in[0,1] .
\end{aligned}
$$

Step 4. Compute the Grey relational grades as the following.

(1) The Grey relational grades for aspired values (the larger the better):

$$
\gamma\left(x^{*}, x_{a}\right)=\sum_{s=1}^{p} w_{s} \gamma\left(x^{*}(s), x_{a}(s)\right) .
$$

(2) The Grey relational grades for worst values (the smaller the better)

$$
\gamma\left(x^{-}, x_{a}\right)=\sum_{s=1}^{p} w_{s} \gamma\left(x^{-}(s), x_{a}(s)\right)
$$

$w_{s}$ is relative weights and $\sum_{s=1}^{p} w_{s}=1$.

Step 5 (ranking based on the concept of TOPSIS (the smaller the better)). The TOPSIS method selects the best alternatives based on criteria in which the distance to the positive ideal solution is the shortest and the distance to the negative ideal solution is the longest [39]:

$$
\gamma_{a}=\frac{\gamma\left(x^{-}, x_{a}\right)}{\gamma\left(x^{*}, x_{a}\right)+\gamma\left(x^{-}, x_{a}\right)} .
$$

\section{Containership Flag Selection under Direct Shipping}

4.1. Data Collection. The survey form was distributed to highlevel managers in charge of ship registrations of Taiwanese container shipping companies that are all Taiwanese capital intending to use the cross-strait direct shipping route, or had already received official approvals from the Taiwanese and Chinese governments. According to the statistics from Department of Navigation and Aviation in Taiwan, there are nine national container shipping companies mainly operating in international cargo carriage in 2011. The survey was conducted by sending out 7 copies of the questionnaires to the companies willing to participate in this study. 6 copies of the 7 questionnaires were returned and checked as valid, and total effective response rate is $85.7 \%$. The number of valid copies meets Teng's [40] suggestion that the appropriate sample number of the AHP method is 5-15. The attributes of surveyed samples are summarized in Table 2.

\subsection{Data Analysis}

4.2.1. Priorities of Criteria and Subcriteria. The relative weights of the criteria and subcriteria were estimated by the aggregate values of the ten experts, and shown in Table 3 .
TABLE 2: Summary attributes of surveyed samples.

\begin{tabular}{lcc}
\hline Attributes of surveyed copies & $\begin{array}{c}\text { Returned } \\
\text { copies }\end{array}$ & $\begin{array}{c}\text { Valid } \\
\text { copies }\end{array}$ \\
\hline Major shipping services & 5 & 4 \\
$\quad$ Container shipping & 2 & 2 \\
$\quad$ Both container and bulk shipping & 7 & $\mathbf{6}$ \\
Subtotal & 6 & 5 \\
Current status on cross-strait direct shipping & & \\
$\quad$ Has already acquired official approvals & 6 & 1 \\
$\quad$ Interested in operating direct shipping & 1 & $\mathbf{6}$ \\
$\quad$ but has not yet acquired official approvals & 7 & \multicolumn{2}{c}{$85.7 \%$} \\
Subtotal & \multicolumn{3}{c}{} \\
\hline Percentage of valid copies &
\end{tabular}

TABle 3: Priorities of criteria and subcriteria.

\begin{tabular}{lcc}
\hline Criteria and subcriteria & $\begin{array}{c}\text { Local } \\
\text { weights }\end{array}$ & $\begin{array}{c}\text { Global } \\
\text { weights }\end{array}$ \\
\hline C1 government policies & $\mathbf{0 . 4 4 1}$ & \\
C11 efficiency of authority & 0.141 & 0.062 \\
C12 vessels recruited in war & 0.083 & 0.037 \\
C13 registry qualifications acquired & 0.358 & 0.158 \\
C14 direct shipping licenses & 0.418 & 0.184 \\
\hline \multicolumn{4}{c}{$\lambda_{\max }=4.072, \mathrm{CI}=0.024, \mathrm{CR}=0.027$} \\
\hline C2 economic factors & $\mathbf{0 . 3 1 7}$ \\
C21 crew costs & 0.220 & 0.070 \\
C22 dual class expenses & 0.160 & 0.051 \\
C23 financing costs & 0.338 & 0.107 \\
C24 tax-related expenses & 0.282 & 0.089 \\
\hline \multicolumn{4}{c}{$\lambda_{\max }=4.155, \mathrm{CI}=0.052, \mathrm{CR}=0.057$} \\
\hline C3 operational flexibility & $\mathbf{0 . 2 4 2}$ \\
C31 employment requirement for & 0.286 & 0.069 \\
Taiwanese seafarers & $\lambda_{\max }=4.074, \mathrm{CI}=0.025, \mathrm{CR}=0.027$ \\
C32 complying with PSC requirements & 0.189 & 0.046 \\
C33 cargo considerations & 0.329 & 0.080 \\
C34 prohibition of the employment of & 0.196 & 0.047 \\
Chinese seafarers & \\
\hline
\end{tabular}

$\lambda_{\max }=3.010$, C.I. $=0.005$; C.R. $=0.008$ for the comparison of criteria with respect to the overall objective.

The consistencies of the test results, as measured by the $C . R$. of the comparison matrix from each of the experts, were all smaller than 0.1. Further, Table 3 shows the C.R. of the aggregate matrix is smaller than 0.1 , indicating consistency. The evaluation criterion having the most profound effect on registry selection of direct shipping was government policies, with the priority weight calculated to be 0.441 . This implies the cross-strait direct shipping route is strictly controlled by Taiwanese and Chinese governments. Followed by the economic factors, with a priority weight of 0.317 , supporting the opinion presented by Lin et al. [10], Llácer [18], Tenold [19], Haralambides and Yang [17], and Alderton 
TABle 4: Performance matrix.

\begin{tabular}{lccccccccccccc}
\hline Alternatives & C11 & C12 & C13 & C14 & C21 & C22 & C23 & C24 & C31 & C32 & C33 & C34 \\
\hline Taiwan & 0.209 & 0.293 & 0.560 & 0.319 & 0.222 & 0.221 & 0.337 & 0.162 & 0.169 & 0.359 & 0.116 & 0.080 \\
Hong Kong & 0.633 & 0.431 & 0.180 & 0.268 & 0.486 & 0.330 & 0.416 & 0.520 & 0.562 & 0.308 & 0.284 & 0.460 \\
China & 0.158 & 0.276 & 0.260 & 0.413 & 0.292 & 0.449 & 0.247 & 0.318 & 0.269 & 0.333 & 0.600 & 0.460 \\
\hline Aspired level & 0.633 & 0.431 & 0.560 & 0.413 & 0.486 & 0.449 & 0.416 & 0.520 & 0.562 & 0.359 & 0.600 & 0.460 \\
Worst level & 0.158 & 0.276 & 0.180 & 0.268 & 0.222 & 0.221 & 0.247 & 0.162 & 0.169 & 0.308 & 0.116 & 0.080 \\
\hline
\end{tabular}

TABLE 5: Difference series.

\begin{tabular}{lccccccccccccc}
\hline Alternatives & C11 & C12 & C13 & C14 & C21 & C22 & C23 & C24 & C31 & C32 & C33 & C34 \\
\hline Taiwan & & & & & & & & & & & \\
$\quad$ Aspired level & 0.424 & 0.138 & 0.000 & 0.094 & 0.264 & 0.228 & 0.080 & 0.358 & 0.393 & 0.000 & 0.484 & 0.380 \\
$\quad$ Worst level & 0.051 & 0.017 & 0.380 & 0.052 & 0.000 & 0.000 & 0.089 & 0.000 & 0.000 & 0.051 & 0.000 & 0.000 \\
Hong Kong & & & & & & & & & & & \\
$\quad$ Aspired level & 0.000 & 0.000 & 0.380 & 0.146 & 0.000 & 0.118 & 0.000 & 0.000 & 0.000 & 0.051 & 0.316 & 0.000 \\
$\quad$ Worst level & 0.475 & 0.154 & 0.000 & 0.000 & 0.264 & 0.109 & 0.169 & 0.358 & 0.393 & 0.000 & 0.168 & 0.380 \\
China & & & & & & & & & & & \\
$\quad$ Aspired level & 0.475 & 0.154 & 0.300 & 0.000 & 0.193 & 0.000 & 0.169 & 0.201 & 0.293 & 0.027 & 0.000 & 0.000 \\
$\quad$ Worst level & 0.000 & 0.000 & 0.080 & 0.146 & 0.071 & 0.228 & 0.000 & 0.157 & 0.100 & 0.025 & 0.484 & 0.380 \\
\hline
\end{tabular}

and Winchester [16] that economic considerations affect flag decisions. The last criterion was operational flexibility, with a priority weight of 0.242 .

The top two important subcriteria are direct shipping licenses and registry qualification sacquired, with priority weights of 0.184 and 0.158 , respectively. Both criteria come from the provisions of the CST Agreement. The rigorous review of the ship's applications by both governments of the Strait may be an important reason for cross-strait transport capacity being arranged based on the principles of "equal participation and orderly competition." The rest of the subcriteria ranked in the order financing costs (0.107), tax-related expenses (0.089), cargo considerations (0.080), crew costs (0.070), employment requirement for Taiwanese seafarers (0.069), efficiency of authority (0.062), dual class expenses (0.051), prohibition of the employment of Chinese seafarers (0.047), complying with PSC requirements (0.046), and vessels recruited in war (0.037). The total weights of the top seven criteria accounted for $75.7 \%$ of the total.

4.2.2. Determining the Performance of Register Location. According to the AHP questionnaire, pairwise comparison of each two-item is all scaled in the range of $1 / 9 \sim 9$. The performance matrix is constructed according to the results of the questionnaires from selected experts, and the maximum and minimum value in each column as the aspired level and worst level were set in Table 4 .

In this step, the difference series are calculated from the difference in the performance of each alternative from the aspired level to the worst level. The results are shown in Table 5.

To obtain the Grey relation grade of all alternatives, we calculate the weight $\left(w_{j}\right)$ of each criterion by the AHP method. The Grey relation coefficient and the grade of the Grey relation of the alternatives are shown in Table 6.
In the final step, the alternatives are ranked according to their relative closeness which was calculated by the concept of TOPSIS. Table 7 summarizes all the results of the evaluation criteria and the ranking of alternatives.

For the ranking of alternatives referring to each subcriterion, Hong Kong achieves the best performance under seven subcriteria, and three of which belong to the criteria of economic factors. These seven highest performance subcriteria are the efficiency of authority, employment requirement for Taiwanese seafarers, tax-related expenses, crew costs, prohibition of the employment of Chinese seafarers, vessels recruited in war, and financing costs. China ranks well in the criteria of operational flexibility and achieves the best performance under four subcriteria of cargo considerations, prohibition of the employment of Chinese seafarers, dual class expenses, and direct shipping licenses. Finally, with the worst performance in half of all twelve subcriteria, Taiwan achieves the best performance only under the subcriteria of registry qualifications acquired and complying with PSC requirements. According to the relative closeness, the most preferred registry selection is Hong Kong, with a 0.475 relative closeness, followed by China (0.504) and Taiwan (0.566). Hence, registering in Hong Kong is the optimal selection for Taiwanese container shipping companies to operating crossstrait container shipping business. Furthermore, we infer the openness of direct shipping across the Taiwan Strait could not be the incentive to attract Taiwanese container shipping companies to register their ships into the national merchant fleet.

\section{Discussions}

Direct shipping across the Taiwan Strait began in 2008, and then more stringent requirements for qualified ships in the CST Agreement made cross-strait shipping into a similar 
TABLE 6: Grey relation coefficient and grade of grey relation of the alternatives.

\begin{tabular}{|c|c|c|c|c|c|c|}
\hline \multirow{2}{*}{ Criteria } & \multicolumn{2}{|c|}{ Taiwan } & \multicolumn{2}{|c|}{ Hong Kong } & \multicolumn{2}{|c|}{ China } \\
\hline & Aspired level & Worst level & Aspired level & Worst level & Aspired level & Worst level \\
\hline C11 & 0.363 & 0.825 & 1.000 & 0.337 & 0.337 & 1.000 \\
\hline $\mathrm{C} 12$ & 0.637 & 0.936 & 1.000 & 0.611 & 0.611 & 1.000 \\
\hline $\mathrm{C} 13$ & 1.000 & 0.389 & 0.389 & 1.000 & 0.446 & 0.752 \\
\hline $\mathrm{C} 14$ & 0.720 & 0.824 & 0.624 & 1.000 & 1.000 & 0.624 \\
\hline $\mathrm{C} 21$ & 0.478 & 1.000 & 1.000 & 0.478 & 0.556 & 0.774 \\
\hline $\mathrm{C} 22$ & 0.515 & 1.000 & 0.671 & 0.689 & 1.000 & 0.515 \\
\hline $\mathrm{C} 23$ & 0.752 & 0.730 & 1.000 & 0.589 & 0.589 & 1.000 \\
\hline $\mathrm{C} 24$ & 0.403 & 1.000 & 1.000 & 0.403 & 0.546 & 0.607 \\
\hline $\mathrm{C} 31$ & 0.381 & 1.000 & 1.000 & 0.381 & 0.452 & 0.708 \\
\hline $\mathrm{C} 32$ & 1.000 & 0.825 & 0.825 & 1.000 & 0.901 & 0.907 \\
\hline $\mathrm{C} 33$ & 0.333 & 1.000 & 0.434 & 0.590 & 1.000 & 0.333 \\
\hline $\mathrm{C} 34$ & 0.389 & 1.000 & 1.000 & 0.389 & 1.000 & 0.389 \\
\hline Grey relational grades & 0.630 & 0.821 & 0.764 & 0.691 & 0.699 & 0.710 \\
\hline
\end{tabular}

TABLE 7: Relative closeness and the ranking of alternatives.

\begin{tabular}{|c|c|c|c|c|c|}
\hline \multirow{2}{*}{ Criteria } & \multirow{2}{*}{ Local weights } & \multirow{2}{*}{ Global weights } & \multicolumn{3}{|c|}{ Performance of alternatives } \\
\hline & & & Taiwan & Hong Kong & China \\
\hline $\mathrm{C} 1$ government policies & 0.441 & & & & \\
\hline C11 efficiency of authority & 0.141 & $0.062(8)$ & $0.209(2)$ & $0.633(1)$ & $0.158(3)$ \\
\hline $\mathrm{C} 12$ vessels recruited in war & 0.083 & $0.037(12)$ & $0.293(2)$ & $0.431(1)$ & $0.276(3)$ \\
\hline $\mathrm{C} 13$ registry qualifications acquired & 0.358 & $0.158(2)$ & $0.560(1)$ & $0.180(3)$ & $0.260(2)$ \\
\hline C14 direct shipping licenses & 0.418 & $0.184(1)$ & $0.319(2)$ & $0.268(3)$ & $0.413(1)$ \\
\hline $\mathrm{C} 2$ economic factors & 0.317 & & & & \\
\hline C21 crew costs & 0.220 & $0.070(6)$ & $0.222(3)$ & $0.486(1)$ & $0.292(2)$ \\
\hline C22 dual class expenses & 0.160 & $0.051(9)$ & $0.221(3)$ & $0.330(2)$ & $0.449(1)$ \\
\hline C23 financing costs & 0.338 & $0.107(3)$ & $0.337(2)$ & $0.416(1)$ & $0.247(3)$ \\
\hline C24 tax-related expenses & 0.282 & $0.089(4)$ & $0.162(3)$ & $0.520(1)$ & $0.318(2)$ \\
\hline C3 operational flexibility & 0.242 & & & & \\
\hline C31 employment requirement for Taiwanese seafarers & 0.286 & $0.069(7)$ & $0.169(3)$ & $0.562(1)$ & $0.269(2)$ \\
\hline C32 complying with PSC requirements & 0.189 & $0.046(11)$ & $0.359(1)$ & $0.308(3)$ & $0.333(2)$ \\
\hline C33 cargo considerations & 0.329 & $0.080(5)$ & $0.116(3)$ & $0.284(2)$ & $0.600(1)$ \\
\hline C34 prohibition of the employment of Chinese seafarers & 0.196 & $0.047(10)$ & $0.080(3)$ & $0.460(1)$ & $0.460(1)$ \\
\hline Relative closeness & & & $0.566(3)$ & $0.475(1)$ & $0.504(2)$ \\
\hline
\end{tabular}

"quasi-domestic" route. According to the result of criteria priority, "government policies" come before "economic factors." This implies the cross-strait shipping route did not totally return to a free-market mechanism. The forbiddance of foreign ships participating in direct shipping does not necessarily result in ships flagging back to Taiwan.

This study indicates direct shipping is not an incentive for containerships to flag back and become part of the Taiwanese national merchant fleet. From the results of the priority of the subcriteria and the performance of the alternatives, direct shipping licenses is the most important subcriterion for container shipping companies, and China has the best performance. This implies the application of cross-strait direct shipping is subject to strict auditing. Even if a ship complies with the requirements of the CST Agreement, it will not necessarily obtain approval from China. Taking the initiative to help shipping companies understand the processes and get direct shipping approvals from China will be an important task for the Taiwanese government.

Registry qualifications acquired is the second important subcriterion, with Taiwan having the best performance. The current ships that meet the registry qualifications requirement in the CST Agreement will be put into operation on the cross-strait shipping in priority rather than changing the flag of FOC ship if the ship type is appropriate. For Taiwanese container shipping companies, to apply for direct shipping with their own national ships can catch market opportunities quickly. Changing the flag from FOC ships or ordering new buildings would be the secondary choice if current capacity is not satisfied.

Hong Kong has advantages in terms of economic factors. A lower or even zero income tax rates accompanying a higher 
emphasis on ship safety made these quasi-FOC locations more attractive. When a ship is registered in Hong Kong, incomes derived from international operations are exempt from profit tax. Cost advantages will make Hong Kong flag ships more competitive. Therefore, although cross-strait shipping is highly controlled by both sides of the Strait, economic factors are still taken seriously in commercial activities. How to make attractive financial measures such as a lower tax rate or other supporting systems will become the important subject for Taiwanese government.

\section{Concluding Remarks}

The CST Agreement affects Taiwanese container shipping companies on flag selection of the ships which intend to carry out operating direct shipping across the Taiwan Strait. This study applied the AHP and GRA methods with TOPSIS to find the optimal flag selection for Taiwanese container shipping companies under the provisions of the CST Agreement.

(1) Intense trade activities between Taiwan and China promoted the signature of the CST Agreement on November 4, 2008, and in the same year, direct shipping began on December 15. Both governments agreed ships owned and registered in Taiwan, China, or Hong Kong may engage in direct cross-strait carriage of cargoes and passengers. Selecting a ship flag is a crucial issue for a successful shipping business because the economics of running a merchant ship are closely related to ship registrations. Moreover, the agreement has greater impact on Taiwanese container shipping companies because they might have to input a fleet rather than a ship to operate a shipping route in order to offer regular schedules and weekly services. Therefore, Taiwanese container shipping companies are interested in the choice of having their ships be flagged in one of these three locations for undertaking direct cross-strait shipping carriage.

(2) The evaluation criterion having the most profound effect on the containership registry location selection of direct shipping is government policies. Further, direct shipping licenses and registry qualifications acquired are the top two factors among twelve subcriteria. Owing to the rigorous review of the ship qualification of cross-strait direct shipping, the current ships meeting the registry qualifications requirement in the CST Agreement will be put into operation on the cross-strait shipping in priority rather than changing the flag of FOC ship if the ship type is appropriate.

(3) The economic factors are the second important criterion, and crew costs, financing costs, and tax-related expenses were ranked 3rd, 4 th, and 6 th of all subcriteria. For these factors, Hong Kong has most of the advantages. These results support previous opinions proposed by Llácer [18], Tenold [19], Haralambides and Yang [17], and Alderton and Winchester [16], Cullianane and Robertshaw [20] that flagging out is much more likely to be based on economic grounds.
However, even though the criteria "government policies" comes before "economic factors," Hong Kong is the optimal flag selection. These results imply that although the cross-strait shipping did not totally return to the market mechanism, economic factors are still taken seriously in the commercial activities.

(4) For undertaking direct cross-strait shipping carriage, the most preferred registry location for Taiwanese container shipping companies is Hong Kong, with a 0.475 relative closeness achieving the best performance under seven subcriteria with the highest performance scores, three of which belong to the criteria economic factors. Followed by China with a 0.504 relative closeness, reaching the best performance under four subcriteria. Taiwan is the worst alternative with relative closeness of 0.566 , and half of all twelve subcriteria are having the worst performance.

According to the abovementioned results, opening direct shipping across the Taiwan Strait may not effectively motivate Taiwanese container shipping companies to register their ships into the national merchant fleet under the provisions of the CST Agreement. For attracting shipping companies to flag back, Taiwanese government have to consider how to help shipping companies to understand the application processes and get direct shipping approvals from China. Further, how to make attractive financial measures such as lower tax rates or other supporting systems will also become the important subject for Taiwanese government.

\section{Conflict of Interests}

The authors declare that there is no conflict of interests regarding the publication of this paper.

\section{Acknowledgment}

The authors would like to thank the National Science Council (Grant NSC 102-2410-H-019-012) of Taiwan for its partial support.

\section{References}

[1] Ministry of Finance, "Foreign trade statistics database," http://web02.mof.gov.tw/njswww/WebProxy.aspx?sys=100\& funid=defjspt 2 .

[2] Taiwan's Mainland Affairs Council, Cross-Strait Sea Transport (CST) Agreement, Taiwan's Mainland Affairs Council, Taiwan, 2008.

[3] J. S. L. Lam, "Patterns of maritime supply chains: slot capacity analysis," Journal of Transport Geography, vol. 19, no. 2, pp. 366374, 2011.

[4] Y. C. Yang, "Assessment criteria for the sustainable competitive advantage of the national merchant fleet from a resource-based view," Maritime Policy and Management, vol. 37, no. 5, pp. 523540, 2010.

[5] R.-H. Chiu, "The liberalization of shipping in Taiwan," Marine Policy, vol. 31, no. 3, pp. 258-265, 2007. 
[6] C. C. Chung, C. C. Hwang, and Y. L. Wong, "An analysis of key influence factors for containership registration in Taiwan," Journal of the Eastern Asia Society for Transportation Studies, vol. 7, pp. 3060-3073, 2007.

[7] J.-L. Guo, G.-S. Liang, K.-D. Ye, and Y. Wu, "Impact of special shipping across the Taiwan straits on the employment of Taiwanese ship officers," Maritime Policy and Management, vol. 34, no. 1, pp. 21-36, 2007.

[8] C. C. Hwang and C. C. Chung, "An analysis of key influence factors for bulk carrier registrations in Taiwan," Transportation Planning Journal, vol. 34, no. 1, pp. 27-62, 2005.

[9] J. S. L. Lam and J. Dai, "A decision support system for port selection," Transportation Planning and Technology, vol. 35, no. 4, pp. 509-524, 2012.

[10] C.-W. Lin, C.-C. Chung, and S.-H. Yang, "An evaluation of containership registrations in Taiwan: application of the grey relation analysis model," Journal of Testing and Evaluation, vol. 39, no. 3, pp. 1-9, 2011.

[11] T.-W. Lee, "Flagging options for the future: a turning point in Korean shipping policy?" Maritime Policy and Management, vol. 23, no. 2, pp. 177-186, 1996.

[12] A. S. Bergantino and P. O'Sullivan, "Flagging out and international registries: main developments and policy issues," International Journal of Transport Economics, vol. 26, no. 3, pp. 447-472, 1999.

[13] A. S. Bergantino and P. B. Marlow, "Factors influencing the choice of flag: empirical evidence," Maritime Policy and Management, vol. 20, no. 2, pp. 157-174, 1998.

[14] B. N. Metaxas, Flags of Convenience: A Study of Internationalization, Gower, Aldershot, UK, 1985.

[15] S. R. Tolofari, Open Registry Shipping: A Comparative Study of Costs and Freight Rates, Gordon and Breach, New York, NY, USA, 1989.

[16] T. Alderton and N. Winchester, "Globalisation and deregulation in the maritime industry," Marine Policy, vol. 26, no. 1, pp. 35-43, 2002.

[17] H. E. Haralambides and J. Yang, "A fuzzy set theory approach to flagging out: towards a new Chinese shipping policy," Marine Policy, vol. 27, no. 1, pp. 13-22, 2003.

[18] F. J. M. Llácer, “Open registers: past, present and future," Marine Policy, vol. 27, no. 6, pp. 513-523, 2003.

[19] S. Tenold, "A most convenient flag-the basis for the expansion of the Singapore fleet, 1969-82," Maritime Policy and Management, vol. 30, no. 3, pp. 255-268, 2003.

[20] K. Cullianane and M. Robertshaw, "The influence of qualitative factors in Isle of Man ship registration decisions," Maritime Policy and Management, vol. 23, no. 4, pp. 321-336, 1996.

[21] A. Odeke, "An examination of bareboat charter registries and flag of convenience registries in international law," Ocean Development and International Law, vol. 36, no. 4, pp. 339-362, 2005.

[22] M. Celik, I. Deha Er, and A. F. Ozok, "Application of fuzzy extended AHP methodology on shipping registry selection: the case of Turkish maritime industry," Expert Systems with Applications, vol. 36, no. 1, pp. 190-198, 2009.

[23] M. Celik and A. Kandakoglu, "Maritime policy development against ship flagging out dilemma using a fuzzy quantified SWOT analysis," Maritime Policy and Management, vol. 39, no. 4, pp. 401-421, 2012.

[24] D. Cockcroft, "Beyond 2000: some thoughts on the future of maritime trade unionism," Maritime Policy and Management, vol. 24, no. 1, pp. 3-8, 1997.
[25] A. M. Goulielmos, "Flagging out and the need for a new Greek maritime policy," Transport Policy, vol. 5, no. 2, pp. 115-125, 1998.

[26] R. S. Toh and S. Y. Phang, "Quasi-flag of convenience shipping: the wave of the future," Transportation Journal, vol. 33, no. 2, pp. 31-39, 1993.

[27] A. W. Veenstra and A. S. Bergantino, "Changing ownership structures in the Dutch fleet," Maritime Policy and Management, vol. 27, no. 2, pp. 175-189, 2000.

[28] M. Stopford, Maritime Economics, Routledge, London, UK, 2008.

[29] J. Hoffmann, R. J. Sanchez, and W. K. Talley, "Determinants of vessel flag," Research in Transportation Economics, vol. 12, no. 1, pp. 173-219, 2004.

[30] K. Mitroussi and P. Marlow, "The impact of choice of flag on ship management," in The Handbook of Maritime Economics and Business, C. T. Grammenos, Ed., Lloyd's List, London, UK, 2010.

[31] T. L. Saaty, The Analytic Hierarchy Process: Planning, Priority Setting and Resource Allocation, McGraw-Hill, New York, NY, USA, 1980.

[32] T. L. Saaty, Multicriteria Decision Making: the Analytic Hierarchy Process, Eta Services Ltd., Suffolk, UK, 1988.

[33] E. W. T. Ngai, "Selection of web sites for online advertising using the AHP," Information and Management, vol. 40, no. 4, pp. 233242, 2003.

[34] H. Duan, W. Zhao, G. Wang, and X. Feng, “Test-sheet composition using analytic hierarchy process and hybrid metaheuristic algorithm TS/BBO," Mathematical Problems in Engineering, vol. 2012, Article ID 712752, 22 pages, 2012.

[35] D. Ju-Long, "Control problems of grey systems," Systems and Control Letters, vol. 1, no. 5, pp. 288-294, 1982.

[36] J. Deng, "Introduction to grey system theory," Journal of Grey System, vol. 1, no. 1, pp. 1-24, 1989.

[37] C.-T. Chen and W.-Z. Hung, "A new decision-making method for stock portfolio selection based on computing with linguistic assessment," Journal of Applied Mathematics and Decision Sciences, vol. 2009, Article ID 897024, 6 pages, 2009.

[38] M. Izadikhah, "Group decision making process for supplier selection with TOPSIS method under interval-valued intuitionistic fuzzy numbers," Advances in Fuzzy Systems, vol. 2012, Article ID 407942, 14 pages, 2012.

[39] C. M. Liu, M. Y. Ji, and W. C. Chuang, "Fuzzy TOPSIS for multiresponse quality problems in wafer fabrication processes," Advances in Fuzzy Systems, vol. 2013, Article ID 496158, 6 pages, 2013.

[40] J. Y. Teng, Project Evaluation: Methods and Applications, National Taiwan Ocean University, Keelung, Taiwan, 2005. 


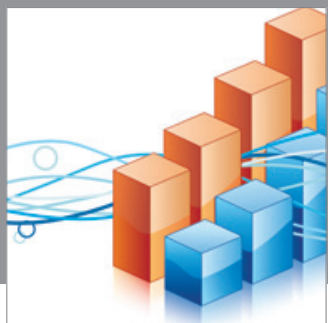

Advances in

Operations Research

mansans

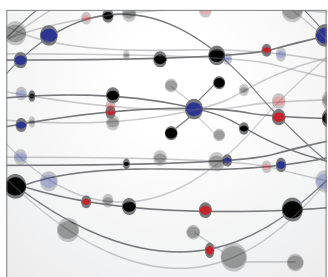

The Scientific World Journal
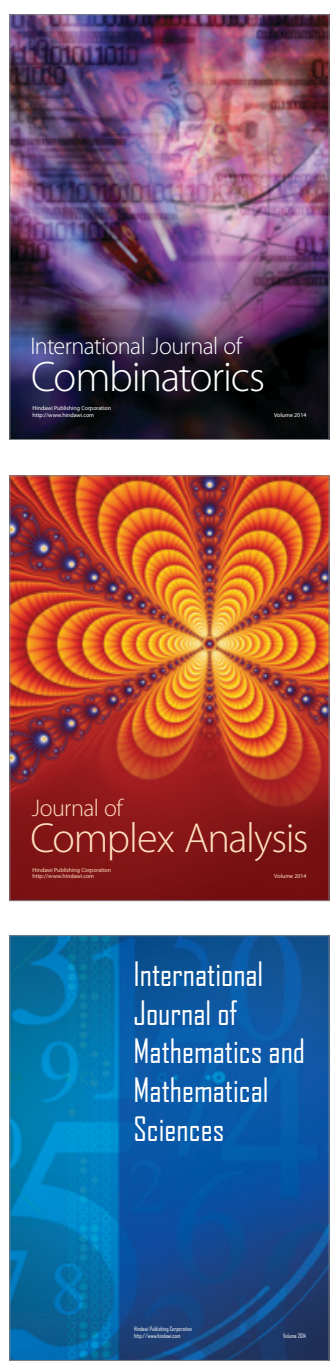
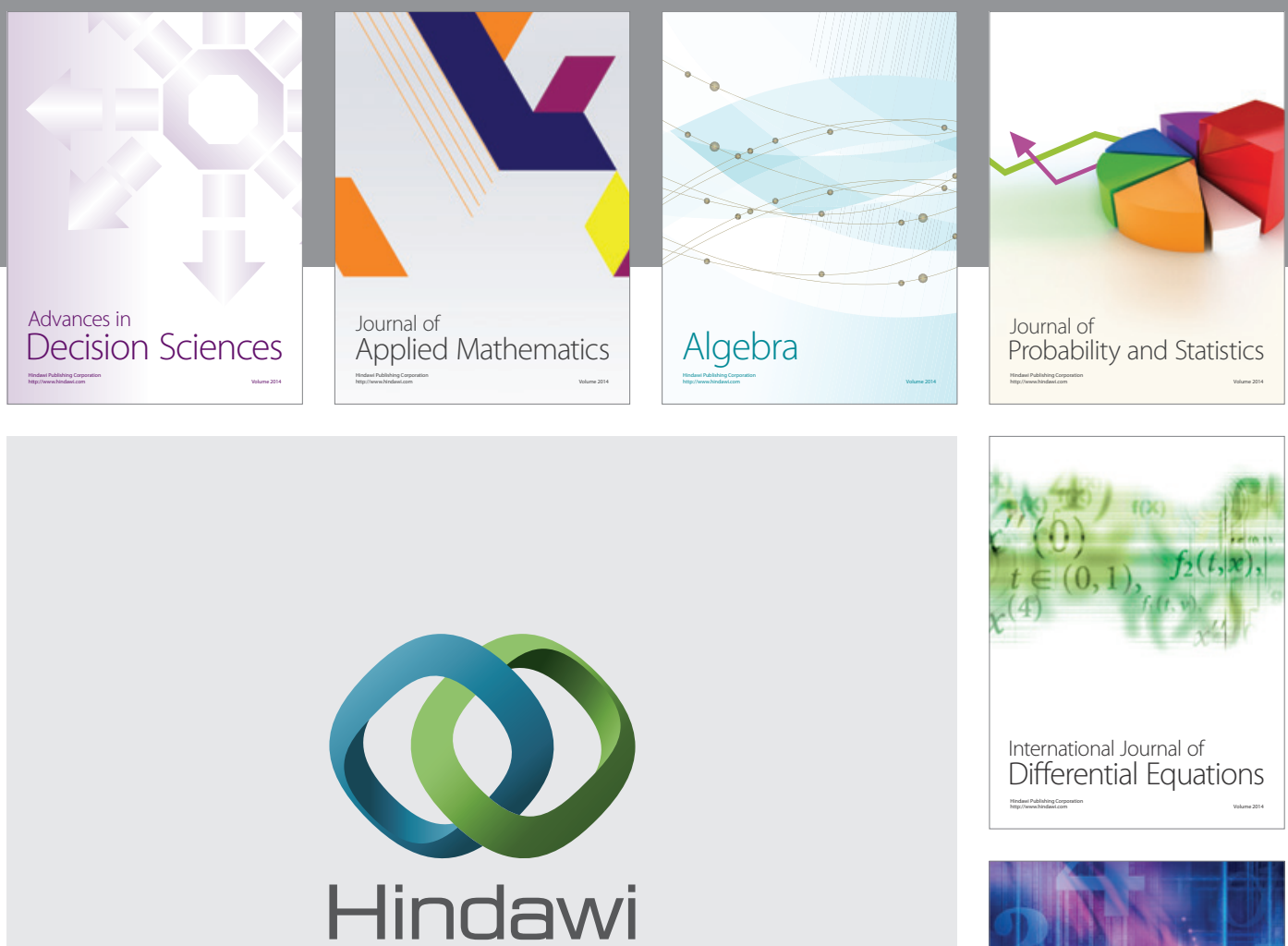

Submit your manuscripts at http://www.hindawi.com
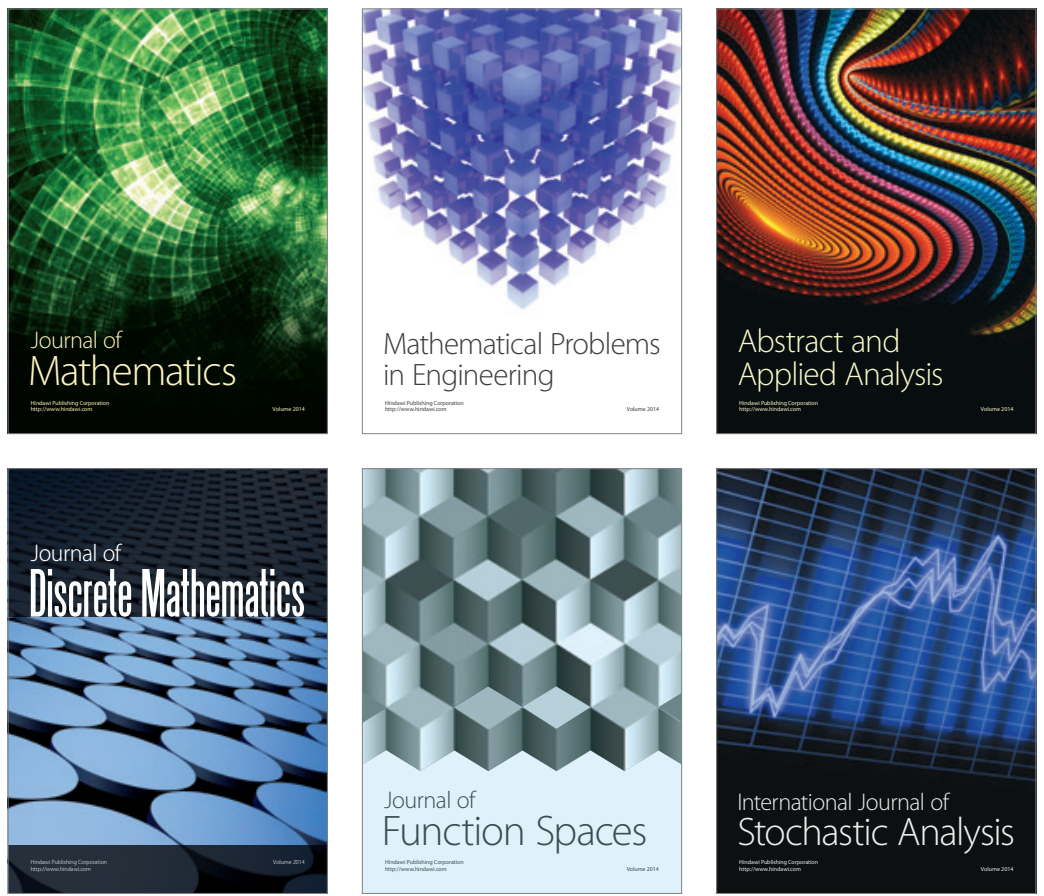

Journal of

Function Spaces

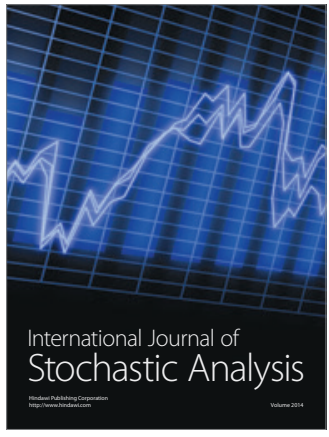

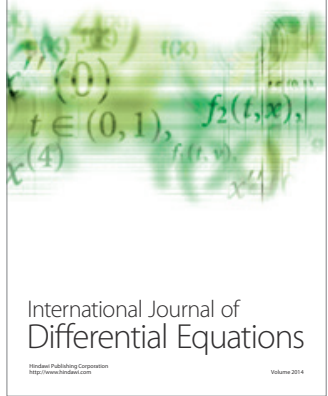
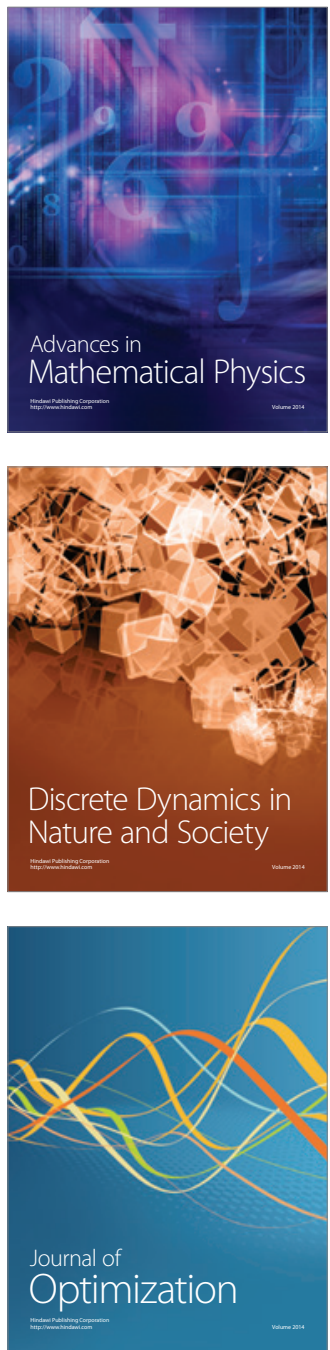